\title{
Pig: Potential Future Meat Animal of India
}

\author{
Neha Thakur ${ }^{1 *}$, Sarita Kumari ${ }^{1}$, Ashish Saini' ${ }^{2}$, Priyanka Meena', \\ Manaswini Sharma ${ }^{2}$ and Manoj Bunkar ${ }^{2}$
}
${ }^{1}$ MVSc LPT, ICAR-Indian Veterinary research institute, Bareilly-243122, U.P., India
${ }^{2}$ MVSc LPT, PGIVER-RAJUVAS, Jaipur-302031, India

*Corresponding author

\section{A B S T R A C T}

\section{Keywords \\ Pork, Pig \\ Production, Pork consumption in India, Pork potential in India \\ Article Info \\ Accepted: \\ 22 January 2019 \\ Available Online: \\ 10 February 2019}

\section{Introduction}

"Eating meat is an instinct; not eating meat is a choice"

Human beings have come a long way from 'food-gatherer' to "food-hunter" and eventually 'food-producer'. Today the world food economy is parallel with the livestock economy. Also, we look up to easy-fixed meals like ready-to-eat (RTE) and ready-tocook (RTC) due to our busy routines and the meat industry has a huge role to play as it offers a wide variety of meat products. Talking about the wide variety and giantess of meat industry one cannot neglect the role pig $\&$ pork play in shaping up the megaeconomies like U.S.A. Globally it is the most accepted meat and for a progressing nation like India whose meat industry has not yet fully explored its potential, pork can be the ultimate meat if its domestic and export potential is fully exploited.

India, besides being a home to various cultures, religions and customs of the world, is also one of the most populous countries across the globe. It is projected that by 2050 India would be feeding a population of 1.7 billion people and hence, the meat 
requirement of country is expected to soar upto 19 millions tons against the current production of 6.4mmt (APEDA, 2016).

\section{Global trends}

More pork is eaten in the work than any other terrestrial meat. About $37 \%$ of all meat consumed in the world is pork (110 million metric tonnes, $\mathrm{mmt})$, ahead of beef $(67 \mathrm{mmt})$ and chicken (104 mmt) (Table 1). In 2011, China had about half of the world pork production $(50 \mathrm{mmt})$, and the USA was second largest in numbers of pigs $(10 \mathrm{mmt})$ with only one-fifth as many pigs as China. Germany was third in pork production with half the USA level (5 mmt) (McGlone, 2013). The EU as a whole is a significant pork producer. Over $80 \%$ of the world's pork is produced in Asia, the EU and North America (Steinfeld et al., 2006).

Population of the world is increasing slowly, but it is anticipated to level in the next 30-50 years (Allen, 2011). Growth in the population would lead to an increased demand for pork (and other meats). Moreover, as developing countries become more affluent, the population shifts its diet from plant-protein based to animal protein based (Godfray et al., 2010). Thus, while world population may reach $50 \%$ higher than today, world meat consumption will likely double in the next 30-50 years (Tilman et al., 2002). Industrialized pork production facilities decrease in value over a 20-30 year period and would be replaced at the end of a depreciation cycle with new and improved facilities. Thus, in the next decades, it is estimated that the industrialized pork production facilities will double in size.

\section{Pig to pork}

It is a known fact that pig is one of the most efficient food converting animal among its domestic counterparts i.e. sheep, got, cattle etc. with an FCR of greater than 3. (3.46 to 4.09) (David, 2012). FCR is a reflection of performance as feeding contributes to about $70-80 \%$ of the total cost of production and this fact can be well utilized for the upliftment of weaker sections of society where pig can serve as a source of cheap income. Especially, in the northeastern regions of our country where there is high pig population. Low or meagre inputs can be fruitfully converted to lucrative results by utilizing the efficient conversion of vegetable matter into high quality protein for human consumption. "Riding the pigs to prosperity" is an idea that has been well received by the progressive farmers of certain states and their tales of success are being used to inspire the rest of the futuristic farmers of the nation (Mizelle, 2012).

\section{Pork production in India}

Pork production in India is growing at a steady pace as the statistics present a grim scenario in terms on consistent stagnancy in total meat share of pork across the nation. Pig is widely distributed in all the eco-regions of the country and its rearing is an important occupation of the rural society especially amongst the tribal masses. People of certain ethnic groups prefer to keep pigs, especially black ones, for festivals and ceremonial purposes. Pigs are concentrated in the NorthEastern Region where almost $40 \%$ of the country's total pig population is reared (Kumaresan et al., 2007). According to the latest livestock census (19th Livestock Census, 2012) the pig population of India is 10.29 million and is showing a declining trend. India's pigs constitute about $1 \%$ of world pig population and the piggery sector is gaining slow but steady momentum during the past few years. Marginal to small farmers and landless laborers owns majority of the pig population. Pork production in India is 
estimated at 464 thousand metric tons in FY 2014-15 (April-March) (GOI), which contributes approximately 8 percent of the country's animal protein sources. From FY 2009-10 to 2014-15, pork production increased at a slow pace with compound annual growth rate of 1.4 percent due to population growth. According to the Livestock Census, 2012, published by Government of India (GOI), the pig population declined by 7.5 percent to 10.3 million from 2007 to 2012. The decline in population may be attributed to disease outbreaks. The eastern and north eastern regions of the country comprise around 63 percent of the pig population. The highest pig population is in state of Assam (1.63 million) followed by Uttar Pradesh (1.33 million), Jharkhand (0.96 million), Bihar (0.65 million) and West Bengal (0.65 million). The pork production is concentrated mainly in the states of Uttar Pradesh (30 percent), followed by north-eastern states (25 percent), (Bihar (15 percent), West Bengal (6 percent), Karnataka (4 percent), Jharkhand (4 percent), and Kerala ( 3 percent).

The majority of the pig population in India is of indigenous breeds (76 percent) though population of cross-bred and exotic pigs increased by 12.7 percent from year 2003 to 2012 (Riedel et al., 2012). The exotic breed mainly comprises Hampshire, Large White York Shire, Duroc, Landrace, and Tamworth while some of the popular indigenous pig breeds include Ghungroo, Niang Megha, Ankamali, Agonda Goan, and TanyVo. India's average meat yield of indigenous breeds is around $35 \mathrm{Kg} / \mathrm{animal}$, which is quite low in comparison to world average of around $78 \mathrm{Kg} / \mathrm{animal}$ (Scarpa et al., 2003).

\section{Pork consumption in India}

The per capita pork consumption in India is negligible with the consumption mainly concentrated in north-eastern states including Assam, Nagaland, Arunachal Pradesh, Manipur, Meghalaya, Mizoram, Sikkim, and Tripura. Other Indian states with high pork consumption include Bihar, Jharkhand, West Bengal, Goa and Kerala. India's Muslim population comprising 14.2 percent of the total population do not eat pork due to religious reasons. Besides, large sections of Indians consumers are suspicious about cleanliness of domestic pork meat as pigs are natural scavenger; the factors further limiting the growth of pork meat sector.

In fact, India's pork consumption can be divided into two segments. First segment being the consumption in the form of fresh pork meat sold through unorganized wet markets and meat vendors. The second segment is the high value imported pork products like sausages, ham, bacon, salami, canned meat products and frozen meat. The hotels and restaurants are the major buyers of the imported pork products, which cater to international travelers and wealthier Indian consumers. There is also retail demand for imported pork products amongst the welltravelled Indian consumers and foreigners residing in India. Though imported pork cuts are preferred for its quality, these are three to four times more expensive than the domestically produced pork cuts (Umberger et al., 2002). The distribution of imported frozen pork products and other meat products is a major challenge due to insufficient cold chain infrastructure across the country. Poultry is the most preferred meat in India which is currently experiencing a strong growth (Kearney, 2010).

\section{Limitations}

Absence of sufficient number of pig breeding farms in the country is a weakness for which sufficient numbers of quality pigs are not available for the fattener farmers as well as to 
the markets. Religious taboo attached with pork consumption is also a major weakness because of which pig farming has not progressed well in the past and confined to a selective group of communities. Tendency of the pig growers to raise pigs to marketable age on zero or negligible inputs is another weakness. Preference of the consumers for pork from the local pig is another weakness for promotion of improved pig with lean meat quality. Lack of adequate support from the development and financial institutions to establish pork based industries has been hindering the growth of pig farming to the desired extent. In the absence of supportive industries in and around the areas where pigs are reared, by-product utilization suffers a setback for which economic return is less. Inadequate availability of high performing improved germplasm for the farmers and entrepreneurs reduces the interest towards commercial pig farming. High cost and more than $60 \%$ deficiency in concentrate feed are potential threats to the piggery sector, which compete with human food for grains. Occurrence of endemic diseases such as classical swine fever and emergence of transboundary diseases like PRRS and porcine circovirus type 2 infections also pose a major concern for piggery sector in India. Limited supply and cost of feed material remains as one of the most prominent bottlenecks in promoting pig farming in the country (Neumann, 2012). Development of economic resource based feeding and increasing bioavailability of the nutrients will remain as key challenges in promoting sustainable pig husbandry since about $70 \%$ of the pig rearing costs are involved on feed. Another challenge, particularly posed due to increasing human population and urbanisation, is the disposal of waste originating from the piggeries. Technological constrains and higher cost of the disposal mechanisms restrict farmers in proper disposal of piggery wastes, resulting in reduced public support for organised pig farms near human dwellings. Therefore, development of low cost effective mechanisms for reducing odours emanating from the pig farms along with appropriate disposal of manure is considered most essential in promotion of piggery sector. Non availability of sewage disposal and by product utilization facility particularly in areas where pig concentration and slaughter is maximum, is another threat from public health point of view for which general public might offer negative views for the growth of pig industry. In another perspective, the challenges for the pig husbandry sector can be subdivided as animal factors (low productivity and growth rate of indigenous animals, poor feed conversion efficiency), feed factors (higher cost of feed ingredients, shortage of feed components, poor resource based feed delivery system, reduced nutrient bioavailability, competition for feed components for other species), environmental factors (incidence of diseases, emerging diseases, climatic stress, disposal of waste generated from pig farms) (Mapiye et al., 2008) and market and technology transfer factors (low availability of quality germplasm, weak market linkages, meeting consumer demands, safety and quality of pork and value added products, awareness among public, technology transfer and adoption, skill development among stakeholders). The major problem faced by small-holder pig farmers in the country is the lack of critical inputs to transform the existing low or zero input system to a vibrant technology driven successful enterprise. It was realized that a small scale economic technology intervention in the form of superior germplasm and package of practices is required to improve income and viability of the enterprise.

\section{Opportunity in pig production}

Pigs, being a livelihood insurance particularly for the weaker sections of the community, 
there exists tremendous opportunities to use pig as a medium of poverty alleviation in the country. The North East in the country where around $50 \%$ of country's pork is consumed by way of procuring live pigs from other parts to the tune of around 1.0 lakh pig heads per annum, a very good opportunity exists for opening up employment generation programmes for rural youth in this sector. It is anticipated that self employment to at least 200 youths in the region would be ensured by production of 500 weaner pigs by each of them per annum. In addition to this, weaner pig purchasers (fattener farmers) can get benefited through the enhanced income through rearing of improved pigs. Selfemployment through pork product processing and employment generation to workers is yet another opportunity through pig husbandry. The current population of 10.29 million (2012) pigs is strength to meet the animal protein deficiency experienced in the country. Ability of the pig to survive and produce under adverse husbandry practices is strength particularly for the weaker, tribal and landless population of the country. Both organic and leaner pork production under traditional managements are additional strengths to bring a meat revolution in the country and thereby provide employment to a large section of the rural poor. India still has significantly large number of people below poverty line. Most of the population are in the tribal belts of the country, where the people are mostly nonvegetarian in their dietary habit. Pork consumption being popular among these populations, improved pig husbandry is an important area in the poverty alleviation programmes. Another opportunity will be utilisation of pig by-products such as hair fibre for value addition and supplementation of existing income from pig farming.

\section{Basic facts about pork}

- Pork is a high-quality protein food. Around $20 \%$ of pork is made up of protein, making it an important muscle building meat (Andersen et al., 2005)

- High calorific value $(242 \mathrm{kCal} / 100 \mathrm{~g})$

- A 3-ounce serving of pork is a good source of potassium, riboflavin and zinc, and is an excellent source of vitamin B6, thiamin, phosphorus, niacin and protein. Pork is naturally low in sodium, too (Brody, 1985).

When people who were obese and overweight switched to a high-protein diet with 25 percent of total calories coming from lean pork and other proteins, they reported an increased feeling of fullness throughout the day (Van Kleef et al., 2012).

\section{Pork Product Processing}

\begin{tabular}{|c|c|}
\hline $\begin{array}{l}\text { Global } \\
\text { Products }\end{array}$ & $\begin{array}{l}\text { Indian } \\
\text { Products }\end{array}$ \\
\hline $\begin{array}{ll}\text { - } & \text { Wide variety } \\
\text { - } & \text { Well- } \\
\text { established } \\
\text { pork firms } \\
\text { - Corporate } \\
\text { giants } \\
\text { involved in } \\
\text { the business } \\
\text { - Multi-million- } \\
\text { dollar industry }\end{array}$ & $\begin{array}{ll}\text { - } & \text { Limited } \\
\text { products } \\
\text { - Mostly } \\
\text { imported } \\
\text { - } \text { Domestic } \\
\text { products of } \\
\text { low quality } \\
\text { - Small } \\
\text { progressive } \\
\text { farmers and a } \\
\text { few } \\
\text { entrepreneurs }\end{array}$ \\
\hline
\end{tabular}

\section{Role of Government}

- $\quad$ NABARD (support the State Piggery Farms, and importation of germplasm)

- DAHD\&F (Guide in Implementing an Effective Bio security Plan in pig farm)

With the vision 2050 of NRCP, here are a few things that the government of India aims at achieving 30\% growth in the piggery sector. Additional objectives include conservation of Indigenous Pig Germplasm, development of 
Technologies Related to Animal Breeding and Propagation of Improved Breeds of Pigs, developing Novel Feeds and Technologies for High Animal Performance. Additionally, provision for early Disease Diagnosis, Prevention and Decision Support Systems for improved production is being eyed at.

Table.1 Meat amount and \% consumed in the world (FAO, 2012)

\begin{tabular}{|l|l|l|}
\hline Meat & Meat consumed, 2012 $(\mathbf{m m t})$ & Percentage of meat $\mathbf{( \% )}$ \\
\hline Pork/Porcine & 110.8 & $37.4 \%$ \\
\hline Poultry & 104.5 & $35.3 \%$ \\
\hline Bovine & 66.8 & $22.6 \%$ \\
\hline Ovine & 13.9 & $4.7 \%$ \\
\hline Total Common Meats & $\mathbf{2 9 6 . 0}$ & $\mathbf{1 0 0 . 0 \%}$ \\
\hline
\end{tabular}

In conclusion, pig production in India holds great prospects and assures a very bright future. But before one can cash in upon this global opportunity that is knocking at our door steps we need to prepare ourselves for it. We require excellence in pig production, health and product processing through innovative research in order to provide technology backstopping for enhanced pork production, employment generation and poverty reduction among socially and economically weaker sections through the medium of pig husbandry.

We need innovative research especially targeting technology delivery mechanisms for rapid growth of the piggery sub-sector and making India a dominant player among the pig producing nations of the world. We being the brains behind this soon-to-be-blooming industry, we need to deliver our services efficiently. The cutting edge research activities in various frontier areas needs to be directed towards augmenting overall nutritional and economic security of pig farmers, transforming piggery to an organized venture for enhanced income, generating employment opportunities and acting as engine for driving socio-economic progress among the citizens of the country and for environmental sustainability of pig production system in the country.
Further, we need to offer more state-of-the-art institutional facilities undertaking high quality, high impact research, in pig and allied industry, offering production support. Pig rearing and pig product production need a head-on approach by the stakeholders to uplift the pig production scenario in India.

If this is done right then in no time we can achieve household food, nutritional and economic security through research, extension and overall human resource development. And make progress in food industry and become leaders in pork production which is without the most preferred and globally accepted meat in the world.

\section{References}

Allen, R.C. 2011. Global economic history: a very short introduction (Vol. 282). Oxford University Press.

Andersen, H.J., Oksbjerg, N., Young, J.F. and Therkildsen, M. 2005. Feeding and meat quality-a future approach. Meat science, 70(3), pp.543-554.

Brody, J.E. 1985. Jane Brody's Good Food Book: Living the High-carbohydrate Way. WW Norton \& Company.

David R. S. 2012. Iowa State University Extension. IPIC 25h. Swine Feed Efficiency: Influence of Market Weight. 
Food-Outlook-FAO, 2013.Available-online: http://www.fao.org/docrep/012/ak341e/ ak341e09. htm\#TopOfPage (accessed on 14 May 2013)

Godfray, H.C.J., Beddington, J.R., Crute, I.R., Haddad, L., Lawrence, D., Muir, J.F., Pretty, J., Robinson, S., Thomas, S.M. and Toulmin, C. 2010. Food security: the challenge of feeding 9 billion people. Science, 327(5967), pp.812-818.

Kearney, J. 2010. Food consumption trends and drivers. Philosophical transactions of the royal society B: biological sciences, 365(1554), pp.2793-2807.

Kumaresan, A., Bujarbaruah, K.M., Pathak, K.A., Chhetri, B., Das, S.K., Das, A. and Ahmed, S.K. 2007. Performance of pigs reared under traditional tribal low input production system and chemical composition of non-conventional tropical plants used as pig feed. Livestock Science, 107(2-3), pp.294298.

Mapiye, C., Mwale, M., Mupangwa, J.F., Chimonyo, M., Foti, R. and Mutenje, M.J. 2008. A research review of village chicken production constraints and opportunities in Zimbabwe. AsianAustralian Journal of Animal Science, 21(11), pp.1680-1688.

McGlone, J.J. 2013. The future of pork production in the world. Towards sustainable, welfare-positive systems. Animals 3(2):401-415.

Mizelle, B. 2012. Pig. Reaktion Books. Neumann, E.J. 2012. Disease transmission and biosecurity. Diseases of swine. John Wiley and Sons Inc., Oxford, UK, pp.141-164

Riedel, Simon, Anne Schiborra, Christian Huelsebusch, Mao Huanming, and Eva
Schlecht. 2012."Opportunities and challenges for smallholder pig production systems in a mountainous region of Xishuangbanna, Yunnan Province, China." Tropical animal health and production 44, no. 819711980.

Scarpa, R., Ruto, E.S., Kristjanson, P., Radeny, M., Drucker, A.G. and Rege, J.E. 2003. Valuing indigenous cattle breeds in Kenya: an empirical comparison of stated and revealed preference value estimates. Ecological Economics, 45(3), pp.409-426.

Steinfeld, H., Wassenaar, T. and Jutzi, S. 2006. Livestock production systems in developing countries: status, drivers, trends. Rev Sci Tech, 25(2), pp.505-516

Tilman, D., Cassman, K.G., Matson, P.A., Naylor, R. and Polasky, S. 2002. Agricultural sustainability and intensive production practices. Nature, 418(6898), p.671.

Umberger, W.J., Feuz, D.M., Calkins, C.R. and Killinger-Mann, K. 2002. US consumer preference and willingness-to-pay for domestic corn-fed beef versus international grass-fed beef measured through an experimental auction. Agribusiness: An International Journal, 18(4), pp.491-504.

Van Kleef, E., Van Trijp, J.C.M., Van Den Borne, J.J.G.C. and Zondervan, C. 2012. Successful development of satiety enhancing food products: towards a multidisciplinary agenda of research challenges. Critical reviews in food science and nutrition, 52(7), pp.611628.

\section{How to cite this article:}

Neha Thakur, Sarita Kumari, Ashish Saini, Priyanka Meena, Manaswini Sharma and Manoj Bunkar. 2019. Pig: Potential Future Meat Animal of India. Int.J.Curr.Microbiol.App.Sci. 8(02): 3149-3155. doi: https://doi.org/10.20546/ijcmas.2019.802.368 